\title{
PENGARUH PEMBERIAN TES FORMATIF TERHADAP HASIL BELAJAR MATEMATIKA MATERI FAKTORISASI SUKU ALJABAR PADA KELAS VIII MTS QUR'ANIYAH BATU KUTA-NARMADA LOMBOK BARAT
}

\author{
Sholiha Nurwulan \\ Universitas Indraprasta PGRI Jakarta, Indonesia \\ Email: Sholihanurwulan1@gmail.com
}

\begin{tabular}{l}
\hline INFO ARTIKEL \\
\hline Diterima \\
12 Juni 2021 \\
Direvisi \\
14 Juni 2021 \\
Disetujui \\
21 Juni 2021
\end{tabular}

Keywords: formative mathematics tests, aljabar \begin{abstract}
The teaching and learning process, it is very important to know the extent to which students understand the material being taught, one way to find out is by conducting an evaluation, namely formative tests. However, many teachers still ignore the evaluation.The study aims to determine whether the provision of
\end{abstract} formative tests affects the mathematics learning outcomes of eighth grade students of MTs Qur'aniyah Batu Kuta on the Faktorisasi Suku Aljabar. The population in this study were all students of class VIII. Therefore, the type of research used is quantitative with experimental research methods with the sampling technique taken using purposive sampling technique, namely by looking at the initial value (pre-test) of the students. The highest average value of the pre-test researcher made it the control class, namely class $A$ and the class that got the lowest average score, the researcher made it the experimental class, namely class VIII C. This study used the pretest-posttest control-group design. Based on the normality test using chi squared $\left(X^{\wedge} 2\right)$, it is obtained $X$ _hitung ${ }^{\wedge} 2$ for post-test data in the experimental class 3.95 and the control class 5.58 which is smaller than $X \_$tabel $^{\wedge} 2$ which is 11.07 , then the data is normally distributed. Whereas for the homogeneity test using the Fisher test, the Fcount of 1.07 was obtained which was smaller than Ftable 2.08, therefore the data was homogeneous. The results of the study were between giving a formative test with mathematics learning outcomes of factorization of algebra in class VIII, there was a significant effect with the calculation of tcount $1.90>$ t table 1.68 with a significant level of 5\%. So Ho is rejected, meaning that there is an effect of giving formative tests on mathematics learning outcomes in the matter of Faktorisasi suku aljabar. The suggets, with the

$\begin{array}{ll}\text { How to cite: } & \text { Nurwulan Sholiha (2021) Pengaruh Pemberian Tes Formatif Terhadap Hasil Belajar Matematika } \\ & \text { Materi Faktorisasi Suku Aljabar Pada Kelas Viii Mts Qur'aniyah Batu Kuta-Narmada Lombok } \\ & \text { Barat. Jurnal Syntax Admiration 2(6). https://doi.org/10.46799/jsa.v2i6.253 } \\ \text { E-ISSN: } & \text { 2722-5356 } \\ \text { Published by: } & \text { Ridwan Institute }\end{array}$


implementation of evaluation at the end of each lesson (formative test) it will have an influence on the mathematics learning outcomes of grade VIII students at MTs Qur'aniyah Batu Kuta-Narmada, especially in the matter of Faktorisasi suku aljabar.

\begin{abstract}
ABSTRAK
Dalam proses belajar mengajar sangat penting untuk mengetahui sejauh mana siswa memahami suatu materi yang diajarkan, salah satu cara mengetahuinya adalah dengan mengadakan evaluasi yaitu tes formatif. Akan tetapi guru masih banyak yang mengabaikan evaluasi tersebut. Penelitian ini bertujuan untuk mengetahui apakah pemberian tes formatif berpengaruh terhadap hasil belajar matematika siswa kelas VIII MTs Qur'aniyah Batu Kuta pada materi faktorisasi suku aljabar. Populasi dalam penelitian ini adalah semua siswa kelas VIII. Oleh karena itu, jenis penelitian yang digunakan adalah kuantitafif dengan metode penelitian eksperimen dengan teknik pengambilan sampel diambil dengan menggunkan teknik purposive sampling yaitu dengan melihat nilai awal (pre-test) siswa. Nilai ratarata tertinggi dari pre-test peneliti jadikan sebagai kelas kontrol yaitu kelas A dan kelas yang mendapatkan nilai rata-rata terendah peneliti jadikan sebagai kelas eksperimen yaitu kelas VIII C. Penelitian ini menggunakan pretest-posttest control-group design. Berdasarkan uji normalitas dengan menggunakan chi kuadrat $\left(\mathrm{X}^{\wedge} 2\right)$ maka didapatkan $\mathrm{X} \_$hitung^2untuk data post-test pada kelas eksperimen 3,95 dan kelas kontrol 5,58 lebih kecil dari $X_{\text {tabel}}{ }^{\wedge} 2$ yaitu 11,07 , maka data terdistribusi normal. Sedangkan untuk uji homogenitas menggunakan uji fisher maka diperoleh Fhitung 1,07 lebih kecil dari Ftabel 2,08 oleh karena itu data homogen. Adapun hasil penelitian adalah antara pemberian tes formatif dengan hasil belajar matematika materi faktorisasi suku aljabar pada kelas VIII terdapat pengaruh yang signifikan dengan hasil perhitungan thitung 1,90 > ttabel 1.68 dengan tingkat signifikan 5\%. Maka Ho di tolak artinya ada pengaruh pemberian tes formatif terhadap hasil belajar matematika pada materi faktorisasi suku aljabar. Hal ini menunjukkan, dengan diterapkannya evaluasi pada setiap akhir pembelajaran (tes formatif) maka akan memiliki pengaruh terhadap hasil belajar matematika siswa kelas VIII MTs Qur'aniyah Batu Kuta-Narmada khususnya pada materi faktorisasi suku aljabar.
\end{abstract}

\section{Kata Kunci :}

tes formatif, hasil belajar matematika, faktorisasi suku aljabar 


\section{Pendahuluan}

Evaluasi sangat penting dalam berbagai aspek kehidupan manusia sehari-hari. Tanpa disadari, evaluasi sering dilakukan, baik untuk diri sendiri, orang lain maupun kegiatan sosial lainnya. Hal ini dapat dilihat dari hal yang sederhana, misalnya bercermin merupakan evaluasi pada penampilan fisik. Di dunia pendidikan pun, evaluasi diperlukan dalam meningkatkan kualitas sumber daya manusia (SDM) dan pada masa yang akan datang kinerja seorang pendidik akan menjadi lebih baik dengan adanya evaluasi (Kurniawati \& Tamba, 2019). Dalam upaya menghasilkan sumber daya manusia yang berkualitas dan memiliki daya saing yang kuat, maka penguasaan matematika sesuatu hal yang mutlak. Matematka sebagai mata pelajaran yang dibelajarkan sejak pendidikan dasar hingga perguruan tinggi memiliki peranan yang strategis dalam rangka menghasilkan SDM yang berdaya saing kuat diera globalisasi (Supardi et al., 2015) Guru Sebagai Fasilitator harus mengetahui kemampuan peserta didik secara individu melalui kegiatan penilaian agar guru bisa mengetahui kemampuan awal peserta didik. Pengukuruan kemampuan peserta didik dapat dilakukan dengan mendiagnosis kesulitan belajar peserta didik secara individu (Anggraeni et al., 2017) Pada umumnya dalam mendiagnosis kesulitan belajar dengan dilakukannya evaluasi.

Adapun landasan evaluasi dalam pembelajaran tedapat pada firman Allah SWT dalam surat Al-Ankabut. Memberitahukan kepada kita, bahwa pekerjaan evaluasi terhadap manusia didik (siswa) merupakan suatu tugas penting dalam rangkaian proses pendidikan yang telah dilaksanakan oleh pendidik, guna mengetahui sejauh mana pemahaman siswa terhadap materi yang telah diajarkan. Hal ini, dapat dipahami dari ayat sebagai berikut: (Kementerian Agama RI, Mushaf Al-Qur'an dan Terjemahan).

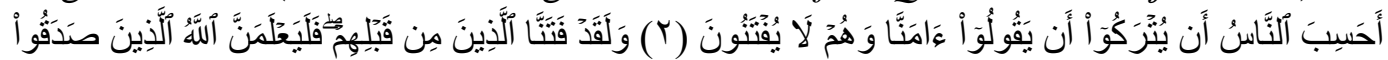

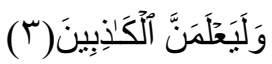

"Apakah manusia itu mengira bahwa mereka dibiarkan (saja) mengatakan: "Kami telah beriman", sedang mereka tidak diuji lagi (2). dan Sesungguhnya Kami telah menguji orang-orang yang sebelum mereka, Maka Sesungguhnya Allah mengetahui orang-orang yang benar dan Sesungguhnya Dia mengetahui orang-orang yang dusta (3)" (QS. al-'Ankabut : 2-3).

Faktor penting dalam pelaksanaan proses pembelajaran adalah pencapaian hasil belajar siswa. Hasil belajar diperlukan guru dalam merefleksi kegiatan pembelajaran karena di dalamnya terdapat proses belajar, penilaian, dan evaluasi (Mahirah, 2017) Evaluasi juga sebagai tolak ukur dalam mengetahui tingkat keberhasilan guru dalam memahamkan siswa terhadap materi yang telah diajarkan (Purwanto \& Darmadi, 2018). Oleh karena itu, perlu adanya alat untuk mengukur kemampuan siswa, alat pengukur itulah yang sering disebut dengan tes.

Tes berfungsi untuk mengetahui tingkat pemahaman siswa dan perbedaan antar siswa, tes juga dapat memberikan motivasi kepada siswa untuk dapat memperbaiki, meningkatkan, dan mempertahankan prestasi dalam proses pembelajaran. Tes dapat 
berfungsi dengan baik dan sesuai dengan tujuannya maka cara pengelolaan hasil tes formatif harus tepat (Slamet \& Maarif, 2014). (Elis Ratna Wulan \& Rusdiana, 2015) Tes hasil belajar atau evaluasi yang lazim dilaksanakan adalah tes diagnostic, tes selektif, tes formatif, tes sumatif, dan tes ujian nasional (UN), dalam penelitian ini peneliti menggunakan tes formatif. Tes formatif adalah penelitian untuk memberikan umpan balik antara peserta didik dan guru dalam kegiatan pembelajaran (Nurjannah, 2017) Namun, efektifitas tes formatif bergantung pada isi umpan balik yang diberikan oleh guru secara berkelanjutan (Voinea, 2018) Hail tes formatif bertujuan untuk memberikan informasi pada guru sejauh mana pemahaman peserta didik sesuai pencapaian hasil pembelajaran setiap kompetensi dasar yang telah ditentukan Karakteristik dari tes formatif diantaranya yaitu : (1) Dilakukan pada akhir setiap satuan pelajaran; (2) Digunakan untuk mengetahui seberapa jauh tujuan pembelajaran sudah tercapai; (3) Memberikan umpan balik perbaikan proses belajar mengajar; (4) Menggunakan tes hasil belajar/ kuesioner/ cara lain; (5) Penilaian penguasaan minimal $70 \%$ dari tujuan pembelajaran yang ingin dicapai (Rofiah et al., 2013)

Materi yang akan digunakan dalam penelitian ini adalah faktorisasi suku aljabar, faktorisasi suku aljabar merupakan materi pokok yang diajarkan pada siswa kelas VIII. Siswa sering kali kesulitan dalam memahami dan mengerjakan soal operasi bentuk aljabar, pecahan aljabar, maupun faktorisasi suku aljabar. Hal ini di karenakan kurangnya latihan atau stimulus yang diberikan oleh guru (Otay, 2013) Sejalan dengan pernyataan di atas, kesalahan yang sering terjadi dalam memecahkan masalah pada sub faktorisasi suku aljabar yaitu kurangnya ketelitian yang disebabkan oleh kurangnya pengontrolan (evaluasi) dalam setiap indikator yang telah diajarkan. Hal ini selaras dengan penelitian yang dilakukan oleh Nunung Fariah dan Leonard dengan judul penelitian "Pengaruh Frekuensi Pemberian Tes Formatif Terhadap Hasil Belajar Matematika" dengan didapatkan hasil pengujian hipotesis menggunakan uji-t dan hasil uji-t menunjukkan thitung $=2,21$ dan ttabel $=1,70$ pada taraf signifikansi 5\% atau ( $a=$ $0,05)$ dan derajat kebebasan ( $\mathrm{db}=38$ ) yang berarti thitung > ttabel 2,21>1,70, maka H0 ditolak dan H1 diterima. Dapat disimpulkan bahwa rata-rata hasil belajar matematika siswa yang diberikan tes formatif secara rutin lebih tinggi daripada rata-rata hasil belajar matematika siswa yang diberikan tes formatif tidak secara rutin. Dengan demikian, terdapat pengaruh frekuensi pemberian tes formatif terhadap hasil belajar matematika siswa (Nunung Fariah dan Leonard : 2017).

Penelitian tentang pengaruh tes formatif terhadap hasil belajar juga dilakukan oleh Mochammad Khafid dalam penelitiannya yang berjudul "Pengaruh pemberian tes formatif terhadap peningkatan hasil belajar pendidikan kesehatan siswa kelas VII SMP Negeri 2 Krian", adapun penelitian tersebut menggunakan penelitian eksperimen melalui pendekatan deskriptif kuantitatif dan berdasarkan hasil analisis data diketahui peningkatan hasil belajar pendidikan kesehatan pada kelompok kontrol sebesar 18,79 \%, sedangkan peningkatan hasil belajar pendidikan kesehatan pada kelompok eksperimen sebesar 32,22 \%, maka persentase peningkatan hasil belajar pendidikan kesehatan pada kelompok eksperimen lebih tinggi 13,43 \% dari kelompok kontrol. Dari hasil 
perhitungan uji beda dengan sampel berbeda (independent sample t-test) diperoleh nilai signifikansi sebesar 0,030< $\rho$ value (sig) 0,05 maka hipotesis diterima. Demikian dapat disimpulkan bahwa ada pengaruh yang signifikan pemberian tes formatif terhadap peningkatan hasil belajar Pendidikan Kesehatan pada siswa kelas VII SMP Negeri 2 Krian. (Mochammad Khafid, 2014). Berdasarkan penelitian di atas sebaiknya guru melakukan tes pada akhir pembahasan setiap topik atau suatu pokok bahasan guna mengetahui tingkat pemahaman siswa. Akan tetapi berdasarkan observasi awal peneliti pada MTs Qur'aniyah tanggal 12-16 Januari 2021, guru masih jarang memberikan tes formatif di setiap akhir pembelajaran. Walaupun terdapat macam-macam bentuk tes dalam buku paket evaluasi pendidikan, namun banyak faktor yang membuat guru tidak memberikan tes formatif yaitu kurangnya pengontrolan guru karena pembelajaran daring, terkadang terkendala jaringan sehingga membuat waktu yang sangat singkat dalam kegiatan belajar mengajar dan kesibukan guru itu sendiri sehingga sudah tidak terpikirkan lagi untuk membuat dan memberikan soal tes pada setiap akhir pembelajaran guna mengetahui sejauh mana peserta didik memahami materi yang telah diajarkan. Pada masa new normal pasca covid-19 tes formatif sangat dibutuhkan karena berfungsi sebagai pengukur tingkat keberhasilan siswa yang belakangan ini belajar online atau daring.

Berdasarkan uraian di atas, karena seringnya guru mengabaikan adanya evaluasi pada setiap indikator yang telah di laksanakan, maka peneliti memandang perlu mengadakan suatu penelitian dengan judul yaitu "Pengaruh Pemberian Tes Formatif Terhadap Hasil Belajar Matematika Materi Faktorisasi Suku Aljabar Pada Siswa Kelas VIII MTs Qur'aniya Batu Kuta-Narmada Lombok Barat"

\section{Metode Penelitian}

Jenis penelitian yang peneliti gunakan adalah penelitian kuantitatif dalam bentuk penelitian eksperimen. Metode eksperimen yang peneliti gunakan adalah metode eksperimen semu (Quashi Eksperimental Design) dengan rancangan Nonequivalent Control Group Design, yaitu dalam desain ini terdapat dua kelompok yakni kelompok eksperimen dan kelompok kontrol yang tidak dipilih secara random (Sugiyono, 2011:79). Dalam desain ini terdapat dua grup yang dipilih secara purposive sampling berdasarkan hasil pre-test dan untuk mengetahui perbedaan keadaan awal antara kelompok eksperimen dan kelompok kontrol. Hasil pre-test yang baik adalah jika nilai kelompok eksperimen tidak berbeda secara signifikan. Masing-masing kelas diberikan pre-test dan post-test.

Dalam penelitian ini, teknik analisis data yang digunakan adalah analisis statistik parametrik. Teknik ini dipilih didasarkan atas tujuan penelitian di atas. Statistik parametrik digunakan untuk menguji parameter populasi melalui data sampel (data yang diperoleh dari sampel). Statistik parametrik mensyaratkan bahwa data setiap variabel yang akan dianalisis harus berdistribusi normal. 
Berdasarkan hasil purposive sampling peneliti mengambil sampel dua kelas, yaitu kelas VIII A dan VIII C. KelasVIII A sebagai kelompok kontrol yang tidak diberikan treatment dan kelas VIII C sebagai kelompok eksperimen yang diberikan tes formatif..

\section{Hasil dan Pembahasan}

Hasil analisis yang diperoleh pada penelitian ini setelah melakukan analisis data berupa uji normalitas, uji homogenitas dan uji hipotesis adalah pada uji normalitas data pre-test dan post-test baik kelas eksperimen maupun kelas kontrol didapatkan bahwa keempat data tersebut berdistribusi normal, yaitu dari hasil uji normalitas dengan menggunakan rumus $\chi^{2}$ didapatkan data hasil pre-test pada kedua sampel terdistribusi normal, pada kelas eksperimen didapat $\chi_{\text {hitung }}^{2}=6,11$ lebih kecil dari $\chi_{\text {tabel }}^{2}=11,07$, dan pada kelas kontrol $\chi^{2}$ hitung $=10,24$ lebih kecil dari $\chi_{\text {tabel }}^{2}=11,07$. Kemudian data tersebut dilakukan uji homogenitas, berdasarkan hasil pre-test diperoleh nilai rata-rata kelas eksperimen sebesar 38,73 dan nilai rata-rata kelas kontrol sebesar 43,57 dan dengan hasil uji Fishernya menunjukkan kedua sampel homogen dengan $F_{\text {hitung }}=1,07$ lebih kecil dari $F_{\text {tabel }}=2,08$, dan hasil analisisnya menyatakan bahwa data tersebut homogen atau mempunyai varians yang sama.

Setelah dilakukan penelitian pada kedua kelas sampel yaitu kelas eksperimen yang diberikan perlakuan berupa pemberian tes formatif dan kelas kontrol yang tidak diberikan tes formatif. Berdasarkan hasil post-test siswa diperoleh nilai rata-rata kelas eksperimen sebesar 77,55 dan kelas kontrol sebesar 64,90. Dari hasil analisis post-test dengan uji Fisher didapatkan data kedua sampel homogen dengan $F_{\text {hitung }}$ sebesar 1,20 lebih kecil dari $\mathrm{F}_{\text {tabel }}$ sebesar 2,08. Dari hasil uji normalitas dengan menggunakan rumus $\chi^{2}$ didapatkan data hasil post-test pada kedua sampel terdistribusi normal, pada kelas eksperimen didapat $\chi_{\text {hitung }}^{2}=3,95$ lebih kecil dari $\chi_{\text {tabel }}^{2}=11,07$, dan pada kelas kontrol $\chi_{\text {hitung }}^{2}=5,58$ lebih kecil dari $\chi_{\text {tabel }}^{2}=11,07$.

Hasil analisis uji-t dari hasil belajar siswa (beda tes awal dan tes akhir) yang mengikuti pembelajaran dengan pemberian test formatif dan dengan tanpa diberikan tes formatif menunjukkan bahwa harga $t_{\text {hitung }}=1,90$ pada taraf signifikan 5\%. Harga ini lebih besar dari harga $t_{\text {tabel }}=1,68$, sehingga dapat disimpulkan bahwa $H_{0}$ ditolak dan $H_{a}$ diterima. Yakni Terdapat pengaruh pemberian tes formatif terhadap hasil belajar matematika materi faktorisasi suku aljabar pada kelas VIII MTs Qur'aniyah Batu Kuta Lombok Barat.

Penelitian yang dilakukan merupakan penelitian eksperimen. Selama empat kali pertemuan, ada dua kali pemberian tes formatif pada setiap akhir pembelajaran. Sebelum melakukan pembelajaran dengan menerapkan tes evaluasi pada akhir satuan pelajaran (tes formatif) atau pada sekolah biasa dikenal dengan ulangan harian, peneliti memberikan pre-test terlebih dahulu pada kedua kelas (kelas kontrol dan kelas eksperimen). Hal ini dilakukan untuk mengetahui bagaimana kemampuan rata-rata kelas kontrol dan kelas eksperimen. Dari hasil pre-test diperoleh nilai rata-rata kelas eksperimen sebesar 38,73 dan nilai rata-rata kelas kontrol sebesar 43,57 dan dengan hasil uji Fishernya menunjukkan kedua sampel homogen dengan $F_{\text {hitung }}=1,07$ lebih kecil dari $F_{\text {tabel }}=2,08$. Dari hasil uji normalitas dengan menggunakan rumus $\chi^{2}$ didapatkan data hasil pre-test pada kedua sampel terdistribusi normal, pada kelas eksperimen didapat $\chi_{\text {hitung }}^{2}=6,11$ lebih kecil dari $\chi_{\text {tabel }}^{2}=11,07$, dan pada kelas kontrol $\chi^{2}$ hitung $=$ 10,24 lebih kecil dari $\chi_{\text {tabel }}^{2}=11,07$. 
Setelah dilakukan penelitian pada kedua kelas sampel yaitu kelas eksperimen yang diberikan perlakuan berupa pemberian tes formatif dan kelas kontrol yang tidak diberikan tes formatif. Berdasarkan hasil post-test siswa diperoleh nilai rata-rata kelas eksperimen sebesar 77,55 dan kelas kontrol sebesar 64,90. Adapun perkembang hasil yang diperoleh kelas eksperimen dan kelas kontrol dapat dilhat pada gambar 5.2. di bawah ini :

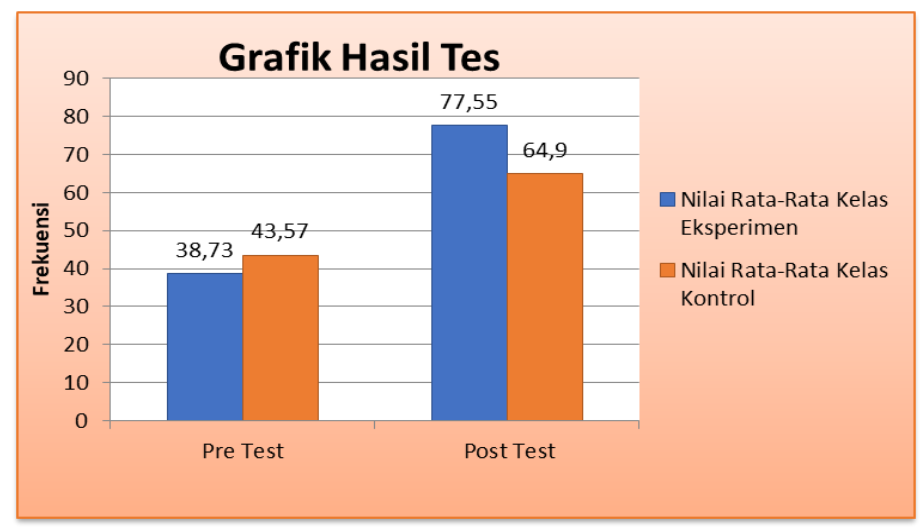

Gambar 1 Grafik Rata-rata Hasil Pre-tes dan Post-tes

Dari hasil analisis post-test dengan uji Fisher didapatkan data kedua sampel homogen dengan $F_{\text {hitung }}$ sebesar 1,20 lebih kecil dari $F_{\text {tabel }}$ sebesar 2,08. Dari hasil uji normalitas dengan menggunakan rumus $\chi^{2}$ didapatkan data hasil post-test pada kedua sampel terdistribusi normal, pada kelas eksperimen didapat $\chi^{2}$ hitung $=3,95$ lebih kecil dari $\chi_{\text {tabel }}^{2}=11,07$, dan pada kelas kontrol $\chi^{2}$ hitung $=5,58$ lebih kecil dari $\chi_{\text {tabel }}^{2}=11,07$.

Kemudian berdasarkan Uji hipotesis dianalisis menggunakan beda tes awal (pretest) dan tes akhir (post-test) siswa kelas eksperimen dan siswa kelas kontrol. Beda tes awal dan tes akhir dianalisis menggunakan uji-t dua pihak. Hasil analisis uji-t dari hasil belajar siswa (beda tes awal dan tes akhir) yang mengikuti pembelajaran dengan pemberian test formatif dan dengan tanpa diberikan tes formatif menunjukkan bahwa harga $t_{\text {hitung }}=1,90$ pada taraf signifikan 5\%. Harga ini lebih besar dari harga $\mathrm{t}_{\text {tabel }}=1,68$, sehingga dapat disimpulkan bahwa $H_{\circ}$ ditolak dan $H_{a}$ diterima. Dari uji hipotesis ini dapat disimpulkan bahwa terdapat pengaruh hasil belajar matematika antara siswa kelas VII MTs Qur'aniyah Batu Kuta-Narmada yang mengikuti pembelajaran dengan diberikan tes formatif dengan siswa yang tidak diberikan tes formatif.

\section{Kesimpulan}

Berdasarkan hasil analisis dan pembahasan penelitian maka dapat disimpulkan :

1. Dari data eksperimen, terdapat pengaruh pemberian tes formatif terhadap hasil belajar siswa pada materi faktorisasi suku aljabar siswa kelas VIII MTs Qur'aniyah Batu Kuta-Narmada

2. Diperoleh bentuk tes formatif isian yang diberikan sebanyak empat kali yang cocok dalam pembelajaran matematika materi faktorisasi suku aljabar

3. Tes formatif cocok diterapkan dalam proses pembelajaran terutama dalam evaluasi pembelajaran 


\section{BIBLIOGRAFI}

Anggraeni, H. B., Subali, B., \& Putri, R. A. (2017). Pengembangan Tes Formatif yang Berfungsi sebagai Tes Diagnostik Kesulitan Belajar Pokok Bahasan Animalia. Pend. Biologi-S1, 6(6), 341-352.Google Scholar

Elis Ratna Wulan, E., \& Rusdiana, A. (2015). Evaluasi pembelajaran. Pustaka Setia.Google Scholar

Kurniawati, W., \& Tamba, W. (2019). Evaluasi Strategi Penerapan Pendidikan Moral di Msi Al Amin Mataram. Jurnal Teknologi Pendidikan: Jurnal Penelitian Dan Pengembangan Pembelajaran, 2, 32-40.Google Scholar

Mahirah, B. (2017). Evaluasi belajar peserta didik (siswa). Idaarah: Jurnal Manajemen Pendidikan, 1(2).Google Scholar

Nurjannah, N. (2017). Mengembangkan Kecerdasan Sosial Emosional Anak Usia Dini Melalui Keteladanan. Hisbah: Jurnal Bimbingan Konseling Dan Dakwah Islam, 14(1), 50-61.Google Scholar

Otay, M. I. (2013). Analisis kesalahan siswa dalam menyelesaikan soal-soal pada materi garis singgung lingkaran. Skripsi, 1(411409063).Google Scholar

Purwanto, A., \& Darmadi, E. A. (2018). Perbandingan Minat Siswa Smu Pada Metode Klasifikasi Menggunakan 5 Algoritma. IKRA-ITH INFORMATIKA: Jurnal Komputer Dan Informatika, 2(1), 43-47.Google Scholar

Rofiah, E., Aminah, N. S., \& Ekawati, E. Y. (2013). Penyusunan Instrumen tes kemampuan berpikir tingkat tinggi fisika pada siswa SMP. Jurnal Pendidikan Fisika, 1(2).Google Scholar

Slamet, S., \& Maarif, S. (2014). Pengaruh bentuk tes formatif assosiasi pilihan ganda dengan reward dan punishment score pada pembelajaran matematika siswa SMA. Infinity Journal, 3(1), 59-80.Google Scholar

Supardi, S. U. S., Leonard, L., Suhendri, H., \& Rismurdiyati, R. (2015). Pengaruh media pembelajaran dan minat belajar terhadap hasil belajar fisika. Formatif: Jurnal Ilmiah Pendidikan MIPA, 2(1).Google Scholar

Voinea, L. (2018). Formative assessment as assessment for learning development. Revista de Pedagogie, 66(1), 7-23.Google Scholar 
Pengaruh Pemberian Tes Formatif Terhadap Hasil Belajar Matematika Materi Faktorisasi Suku Aljabar Pada Kelas Viii Mts Qur'aniyah Batu Kuta-Narmada Lombok

\section{Copyright holder :}

Sholiha Nurwulan (2021)

First publication right:

Jurnal Syntax Admiration

This article is licensed under:

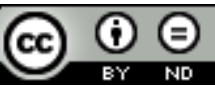

